ISSN (Print): 2615-613X || ISSN (Online): 2615-6083

\section{The Correlation between Students' Reading Comprehension and Their Writing Skill at MTsN 5 Pandeglang}

\author{
Veny Agustini Prianggita1 ${ }^{1}$, Mochammad Habibi \\ ${ }^{1}$ Teacher Training and Education Faculty of Universitas Mathla'ul Anwar Banten
}

\begin{abstract}
This study discusses the ability to read and write. The study aims to answer some problems, namely: 1) Knowing students' reading comprehension, 2) Knowing students' writing skill, and 3) To obtain whether there is a significant relationship between students' reading comprehension and writing skills or not. This research uses Mix method. The population is 183 students of MTs. Negeri 5 Pandeglang. The researcher took 30 students as sample. To test the research hypothesis, the researcher collected data analysis using inferential statistical techniques using Product Moment formula. The finding of research hypothesis shows that: 1) The level of students' comprehension in reading was very low. This could be seen from the analysis that shows the mean 59.7. 2) The level of students' writing skill was in the medium category. This could be seen from the analysis, showing the mean 68. 3) There is a significant positive relationship between reading ability and writing ability. Based on the quantitative analysis, the results of the research show that the observation value $r$ is 0.963 above the $5 \%$ rejection limit of 0.361 and the $1 \%$ rejection limit of 0.461 , in other words $0.963>0.463$ at the $5 \%$ level and 0.361 $>0.963$ at the $1 \%$ level. Thus the result is stated significant and the proposed hypothesis is accepted.
\end{abstract}

This is an open access article distributed under the terms of the Creative Commons Attribution 4.0 International License, which permits unrestricted use, distribution, and reproduction in any medium, provided the original work is properly cited. (๑) 2018 Veny Agustini Prianggita, Mochammad Habibi.

\title{
INTRODUCTION
}

English is foreign language in Indonesia; many students in Indonesian schools have difficulty to master English. The facts from investigation in MTs. Negeri 05 Pandeglang shows that the students have difficulties to master English. There are many reasons showed by the students. By pre research, researcher knew the students have difficulties to master English because the students are not motivated to study English, bad assumption about English and low facilities in the school to support their English study.

As a language that should be mastered, English has four language skills. They are listening, reading, speaking, and writing. These skills are always learnt at school completely and the learners are

\footnotetext{
${ }^{1}$ Corresponding author's address: Teacher Training and Education Faculty of Universitas Mathla'ul Anwar, Banten, Indonesia e-mail: venyagustinibaby@gmail.com
} 
expected to have the ability in those language skills. In English, we do not only have to master spoken language but also have to master written one. This is because written can be used as a media to communicate effectively. By using written text, someone can deliver his/her ideas to everyone without limitation of time.

According to Camille Blachowicz and Donna Ogle (2008:15):

"Reading is essential; it is the process by which people gain information and ideas from books, newspapers, manuals, letters, contracts, advertisements and a host of other materials. Using strategies for constructing meaning before, during and after reading will help students connect what they read now with what they have learned in the past".

In addition, Jeremy Harmer (2007:112) said that: "writing is used as an aide-memoire or practice tool to help students practice and work with language they have been studying". In other words, the process of writing is important skill that demands to express ideas, think, feel, also perceive then interprets it into written form. In addition, writing also needs many abilities such as diction, interrelated paragraph, language style, and so on. He further explained that complexity of writing to compose a good essay includes grammatical skills, contents, stylistic, mechanical, idiom, and also vocabulary.

In order to obtain information and knowledge of grammatical rules, besides by learning using textbooks, learners can get various kinds of information by reading comprehension. Because, Reading comprehension is a process of simultaneously extracting and constructing meaning through interaction and involvement with written language. Simply knowing that reading and writing are intimately connected processes isn't enough.

In order to help children to develop, these two essential skills, parents and teachers need to apply this knowledge when working with them. Here are a few strategies for using reading and writing to reinforce development of literacy skills. Therefore, Reading a variety of genres helps children learn text structures and language that they can transfer to their own writing. In addition, reading provides young people with prior knowledge that they can use in their stories. One of the primary reasons that we read is to learn. Especially while we are still in school, a major portion of what we know comes from the texts we read. Since writing is the act of transmitting knowledge in print, we must have information to share before we can write it. Therefore, reading plays a major role in writing.

Based on researcher's experience and observation which has been done with the English teacher in MTs Negeri 05 Pandeglang, the learners find difficulty in both organizing and arranging the sentences when writing. Thus, they also lack of capability in using correct grammatical rules. They need to get more information in order to make their both knowledge and ideas developed. So they can write without making incorrect tense and lack of ideas.

Based on the description above, the researcher is really interested to investigate "The Correlation between Students' Reading Comprehension and Their Writing Skill in Eight Grade at MTs Negeri 05 Pandeglang." The researcher would like to find out whether there is a significant correlation between students' reading comprehension and their writing skill.

Based on the background of the problems, the research problems of this research is "Is there any significant correlation between students reading comprehension and their writing skill at eighth grade in MTs Negeri 05 Pandeglang?".

Typically writing is taught based on a prescribed textbook in primary schools. Most teachers simply stick to the textbook and adopt a very traditional method. A typical composition lesson goes as follows: the teacher teaches the class a sample of writing in the unit, which usually consists of several sentences describing a person or an object.

According to Juli Kendall \& Outey Khuon (2006:37): 
"Writing is all about making meaning. Teaching writing to English Language Learners (ELLs) can be a challenge because they frequently get confused about what they want to say as they work. The reason we teach them to write using the strategies of proficient writers is because our overall goal is to help ELLs know what they are doing well enough so that they can explain it clearly to their readers".

Reading comprehension is one of the pillars of the act of reading. When people read the text, they engage in complex array of cognitive process. They are simultaneously using their awareness and understanding of phonemes, phonics (connection between letters and sound and the relationship between sounds, letters and words) and ability to comprehend construct meaning from the text.

According to RAND Reading Study Group in (Bozena Kwiatkowska-White 2012:3), Reading comprehension is "the process of simultaneously extracting and constructing meaning through interaction and involvement with written language". According to I.S.P. Nation (2009) "Reading is a source of learning and a source of enjoyment." and then Jeremy Harmer (2007:99) said that:

"Reading is useful for language acquisition. Provided students more or less understand what they read, the more they read the better they get it, reading also has a positive effect on students' vocabulary knowledge, on their spelling and on their writing".

Hypotheses of the research are:

\section{Ha (alternative hypotheses)}

There is a significant correlation between students' reading comprehension and their writing skill.

\section{Ho (nul hypotheses)}

There is no significant correlation between students' reading comprehension and their writing skill.

\section{METHOD}

This research uses combination method or mixed method. According to Sugiyono (2017) "Metode penelitian kombinasi (mixed methods) adalah suatu metode penelitian yang mengkombinasikan atau menggabungkan antara metode kuantitatif dan metode kualitatif untuk digunakan secara bersama-sama dalam suatu kegiatan penelitian sehingga diperoleh data yang lebih komprehensif, valid, reliabel dan objektif".

Based on that opinion, mixed method utilizes two methods, quantitative and qualitative methods, to be utilized in an observational activity deeply. So data gotten is more complete and comprehensive. In this research, the researcher will use quantitative and qualitative method.

This research was conducted in MTs 05 Pandeglang, eight grade of students as the population. Researcher took one class as a sample. The sample is class VIII A. It was selected based on purposive sampling. According to Riduwan (2011:11) sampling technique is a way to get sample that representative from population used by researcher if they have certain consideration in collecting sample or sampling for a particular purpose. Thus, this sampling is suitable for correlation study which representative observed and analyzed.

Success of a research can be determined by the instrument that used, because data which is necessary to answer the problem in the study has obtained by the research instrument. Sugiyono (2017: 102) said that "instrument of research is a measures in a research. It means instruments in the research should be better in order to produce the data correctly".

According to Sugiyono (2017:137) "wawancara digunakan sebagai teknik pengumpulan data apabila ingin melakukan studi pendahuluan untuk menentukan permasalahan yang harus diteliti, dan juga apabila peneliti ingin mengetahui hal-hal dari responden yang lebih mendalam dan jumlah respondennya sedikit/kecil". 
Based on that opinion, interview is utilized as technique of data collecting if researcher wants to do study foreword to determine about problem which is analyzed, and also if researcher wants to know something of more respondent visceral.

Belows are the instruments for interview:

Resource: English teacher

1. RPP used

2. Curriculum used

3. Strategy understanding of reading and writing ability

4. Methods of reading and writing ability

5. Obstacles from improving reading and writing skills

6. Evaluation of reading and writing

Resource: Students

1. Strategy of English teacher

2. Skills of writing and reading comprehension

3. Motivation to study English

4. Evaluation of reading and writing

In this research, the researcher uses interview to get the data. This interview will be given to the students and the English teacher of MTs Negeri 05 Pandegalang. It is to find out the qualitative data from the students about English especially in reading comprehension and their writing skill.

Test, in accordance with the type of assessment undertaken in this study, which does the scoring on some important components in a discussion-shaped article and know in detail the errors that exist, then the model rubric used in this study is analytic. One of the most frequently used analytical rubrics in judging writing is the rubric made by Jacobs et.al (1981: 103). This Jacobs assessment rubric focuses on five criteria: organization, idea development, grammar, vocabulary, and mechanics.

In this research, the researcher uses descriptive text to test the students' writing skill, where the students have to make descriptive text about someone and to measure the reading comprehension, the researcher uses short essay. To measure the validity and reliability of these test, the researcher uses Person product moment.

The objective of correlation research is to find correlation and if it has, how big the correlation is (Arikunto, 2010: 318). The writer conducted the data using correlation product moment. He measured the correlation between two variables, reading and writing with the following formula:

$$
R_{x y}=\frac{\sum x y}{\sqrt{\left(\sum_{x^{2}}\right)\left(\sum y^{2}\right)}}
$$

Notes:

$R_{x y}=$ The coefficient of correlation between $\mathrm{x}$ and $\mathrm{y}$ variables

$\sum x y=$ The sum of multiply result the original score from $\mathrm{x}$ and $\mathrm{y}$ variables

$\sum x^{2}=$ The sum of squared score in $\mathrm{x}$

$\sum y^{2}=$ The sum of squared score in $\mathrm{y}$

(Sugiyono, 2017).

In analyzing the hypothesis, the researcher used tcount that has formula as follow:

Notes:

$$
t_{\text {count }}=\frac{r \sqrt{n-2}}{\sqrt{1-r^{2}}}
$$

tcount =the $t$ value

$\mathrm{r} \quad=$ the value of coefficient correlation

$\mathrm{n} \quad=$ the sum of sample

1 and 2 =the constant number 
The criteria of significant value is as follow:

If $t_{\text {count }} \leq t_{\text {table }}$; it means $H_{0}$ is received

If $t_{\text {count }} \geq t_{\text {table }}$; it means $H_{o}$ is refused or $H_{a}$ is received

In analyzing the collected data, the researcher uses statistical method, because the research used is quantitative research. The purpose of this study is to simplify the data in a form that is easier to read and interpret. The researchers in analyzing this data include these stages, they are:

1) Description of Data Variable $X$ (Reading comprehension)

In the preliminary analysis, the researchers input the data collected into the frequency distribution table to facilitate the next data processing. In this preliminary analysis the figures obtained from the reading comprehension and writing skills in MTs Negeri 5 Pandeglang

2) Test Hypothesis

This analysis is used to fill the frequency distribution that has been analyzed in the introduction, then included in the formula of product moment correlation.

\section{RESULT AND DISCUSSION}

\section{Description of Reading Comprehension Score}

From the test of reading comprehension, the researcher got the score as follow:

Table 1. Score of Variable X (Reading Comprehension)

\begin{tabular}{cc} 
Students No. & Score \\
\hline 1 & 20 \\
2 & 30 \\
3 & 60 \\
4 & 80 \\
5 & 20 \\
6 & 30 \\
7 & 60 \\
8 & 80 \\
9 & 20 \\
10 & 40 \\
11 & 60 \\
12 & 80 \\
13 & 20 \\
14 & 70 \\
15 & 80 \\
16 & 70 \\
17 & 80 \\
18 & 70 \\
19 & 80 \\
20 & 70 \\
21 & 80 \\
22 & 50 \\
23 & 70 \\
24 & 80 \\
25 & 50 \\
26 & 70 \\
27 & 80 \\
28 & 50 \\
29 & 70 \\
30 & 70 \\
\end{tabular}


Based on the table above, the researcher counted the mean of the score of reading comprehension and variable quality, as follow:

a. Counting the interval

$$
\begin{aligned}
\mathrm{K} & =1+3.3 \log \mathrm{n} \\
& =1+3.3(1.4771) \\
& =1+4.87433 \\
& =5.87433
\end{aligned}
$$

b. Counting range.

$$
\begin{aligned}
\mathrm{R} & =\mathrm{H}-\mathrm{L}+1 \\
& =(80-20)+1=61 \\
\mathrm{H} & =\text { highest score } \\
\mathrm{L} & =\text { lowest score }
\end{aligned}
$$

c. Counting interval value.

$$
\begin{aligned}
1 & =\frac{R}{K} \\
& =\frac{61}{6} \\
& =6 . \\
& =10.1 \longrightarrow 10
\end{aligned}
$$

The count of interval is 6 and class interval is 10.

Table 2. Distribution data of Variable X (Reading Comprehension)

\begin{tabular}{cccc}
\hline No. & Interval & $\begin{array}{c}\text { Frequency } \\
\text { Absolutee }\end{array}$ & $\begin{array}{c}\text { Frequency Relative } \\
(\mathbf{\%})\end{array}$ \\
\hline 1 & $20-30$ & 6 & 20 \\
\hline 2 & $31-40$ & 1 & 3.33 \\
\hline 3 & $41-50$ & 3 & 10 \\
\hline 4 & $51-60$ & 3 & 10 \\
\hline 5 & $61-70$ & 8 & 26.66 \\
\hline 6 & $71-80$ & 9 & 30 \\
\hline & & $\mathbf{3 0}$ & $\mathbf{1 0 0}$ \\
\hline
\end{tabular}

From the distribution table above, it can be made the histogram as follow:

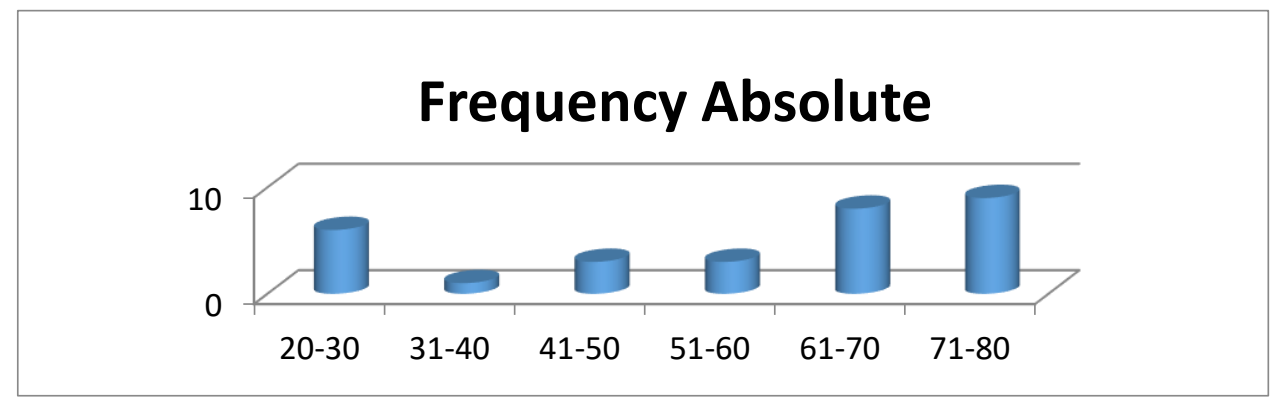

\section{Picture 1. Diagram of Absolute Frequencies of Reading}

Based on the histogram, the mode in the interval is 71-80 with frequencies 9.

\section{Description of writing skill}

Based on the test of writing skill, the score of writing test can be shown as follows: 
Table 3. Score of Variable Y (Writing Skill)

\begin{tabular}{cc} 
Students No. & Score \\
\hline 1 & 31 \\
2 & 40 \\
3 & 70 \\
4 & 80 \\
5 & 31 \\
6 & 50 \\
7 & 70 \\
8 & 80 \\
9 & 31 \\
10 & 50 \\
11 & 70 \\
12 & 80 \\
13 & 40 \\
14 & 70 \\
15 & 80 \\
16 & 70 \\
17 & 80 \\
18 & 70 \\
19 & 90 \\
20 & 70 \\
21 & 90 \\
22 & 60 \\
23 & 80 \\
24 & 90 \\
25 & 60 \\
26 & 80 \\
27 & 90 \\
28 & 70 \\
29 & 80 \\
30 & 80 \\
\hline
\end{tabular}

From the data above, the next step is counting distribution frequencies of writing skill and counting mean.

a. Counting interval

$$
\begin{aligned}
\mathrm{K} & =1+3,3 \log \mathrm{n} \\
& =1+3,3(1,4771) \\
& =1+4,87433 \\
& =5,87433 \longrightarrow 6
\end{aligned}
$$

b. counting Range

$$
\begin{aligned}
\mathrm{R} & =\mathrm{H}-\mathrm{L}+1 \\
& =(90-31)+1=60 \\
\mathrm{H} & =\text { highest score } \\
\mathrm{L} & =\text { lowest score }
\end{aligned}
$$

c. Counting interval score

$$
\begin{aligned}
\text { I } & =\frac{R}{K} \\
& =\frac{60}{6} \\
& =10
\end{aligned}
$$

So the sum of interval is 6 and class interval is 10 . the researcher got qualification and interval score as follow: 
Table 4. The Distribution Data Frequencies of Y (Writing Skill)

\begin{tabular}{cccc}
\hline No. & Interval & Frequency Absolute & Frequency Relative (\%) \\
\hline 1 & $31-40$ & 5 & 16.67 \\
\hline 2 & $41-50$ & 2 & 6.67 \\
\hline 3 & $51-60$ & 2 & 6.67 \\
\hline 4 & $62-70$ & 8 & 26.67 \\
\hline 5 & $71-80$ & 9 & 30 \\
\hline 6 & $81-90$ & 4 & 13,33 \\
\hline & & $\mathbf{3 0}$ & $\mathbf{1 0 0}$ \\
\hline
\end{tabular}

From the distribution table above, it can be made the histogram as follow:

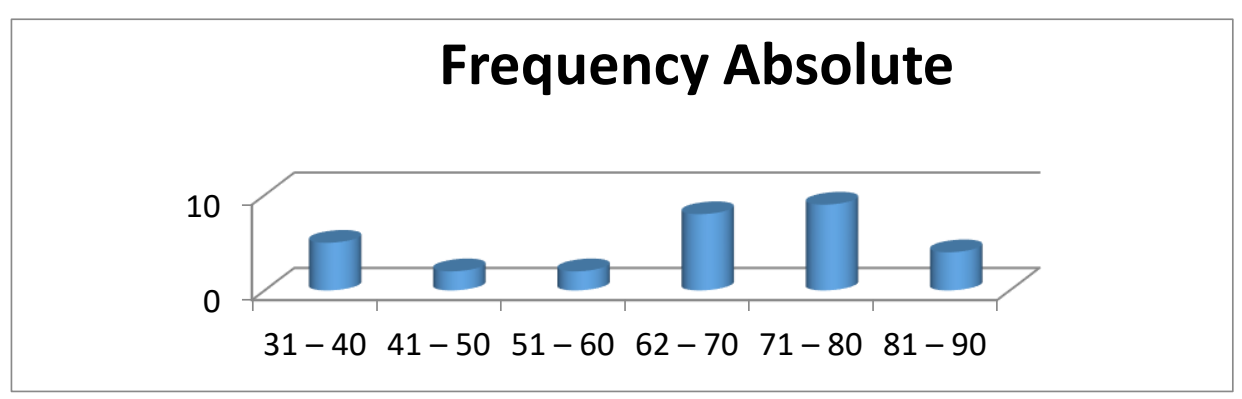

Picture 2. Diagram of Absolute Frequencies of Writing

According to histogram above it can be seen the mode of interval 71-80 with frequencies 9.

\section{Hypothesis Analysis}

To measure the hypothesis of this research of both variable $X$ and $Y$, the researcher used Pearson Product Moment formula.

Table 5. Correlation between Students' Reading Comprehension and Their Writing Skill

\begin{tabular}{|c|c|c|c|c|c|c|c|}
\hline No & $X$ & $\left(X_{1}-X\right) X$ & $X^{2}$ & $\mathbf{Y}$ & $\left(Y_{1}-Y\right) Y$ & Y2 & $X Y$ \\
\hline 1 & 20 & -39.7 & 1573.44 & 31 & -36.8 & 1351.79 & 1458.411 \\
\hline 2 & 30 & -29.7 & 880.11 & 40 & -27.8 & 770.99 & 823.7444 \\
\hline 3 & 60 & 0.3 & 0.11 & 70 & 2.2 & 4.84 & 0.733333 \\
\hline 4 & 80 & 20.3 & 413.44 & 80 & 12.2 & 148.84 & 248.0667 \\
\hline 5 & 20 & -39.7 & 1576.09 & 31 & -36.8 & 1354.24 & 1460.96 \\
\hline 6 & 30 & -29.7 & 882.09 & 50 & -17.8 & 316.84 & 528.66 \\
\hline 7 & 60 & 0.3 & 0.09 & 70 & 2.2 & 4.84 & 0.66 \\
\hline 8 & 80 & 20.3 & 412.09 & 80 & 12.2 & 148.84 & 247.66 \\
\hline 9 & 20 & -39.7 & 1576.09 & 31 & -36.8 & 1354.24 & 1460.96 \\
\hline 10 & 40 & -19.7 & 388.09 & 50 & -17.8 & 316.84 & 350.66 \\
\hline 11 & 60 & 0.3 & 0.09 & 70 & 2.2 & 4.84 & 0.66 \\
\hline 12 & 80 & 20.3 & 412.09 & 80 & 12.2 & 148.84 & 247.66 \\
\hline 13 & 20 & -39.7 & 1576.09 & 40 & -27.8 & 772.84 & 1103.66 \\
\hline 14 & 70 & 10.3 & 106.09 & 70 & 2.2 & 4.84 & 22.66 \\
\hline 15 & 80 & 20.3 & 412.09 & 80 & 12.2 & 148.84 & 247.66 \\
\hline 16 & 70 & 10.3 & 106.09 & 70 & 2.2 & 4.84 & 22.66 \\
\hline 17 & 80 & 20.3 & 412.09 & 80 & 12.2 & 148.84 & 247.66 \\
\hline 18 & 70 & 10.3 & 106.09 & 70 & 2.2 & 4.84 & 22.66 \\
\hline
\end{tabular}




\begin{tabular}{rrrrrrrr}
\hline No & $\mathbf{X}$ & $\mathbf{( \mathbf { X } _ { 1 } - \mathbf { X } ) \mathbf { X }}$ & \multicolumn{1}{c}{$\mathbf{X}^{\mathbf{2}}$} & $\mathbf{Y}$ & $\mathbf{( \mathbf { Y } _ { 1 } - \mathbf { Y } ) \mathbf { Y }}$ & \multicolumn{1}{c}{$\mathbf{Y}$} & \multicolumn{1}{c}{$\mathbf{X} \mathbf{}$} \\
\hline 19 & 80 & 20.3 & 412.09 & 90 & 22.2 & 492.84 & 450.66 \\
\hline 20 & 70 & 10.3 & 106.09 & 70 & 2.2 & 4.84 & 22.66 \\
\hline 21 & 80 & 20.3 & 412.09 & 90 & 22.2 & 492.84 & 450.66 \\
\hline 22 & 50 & -9.7 & 94.09 & 60 & -7.8 & 60.84 & 75.66 \\
\hline 23 & 70 & 10.3 & 106.09 & 80 & 12.2 & 148.84 & 125.66 \\
\hline 24 & 80 & 20.3 & 412.09 & 90 & 22.2 & 492.84 & 450.66 \\
\hline 25 & 50 & -9.7 & 94.09 & 60 & -7.8 & 60.84 & 75.66 \\
\hline 26 & 70 & 10.3 & 106.09 & 80 & 12.2 & 148.84 & 125.66 \\
\hline 27 & 80 & 20.3 & 412.09 & 90 & 22.2 & 492.84 & 450.66 \\
\hline 28 & 50 & -9.7 & 94.09 & 70 & 2.2 & 4.84 & -21.34 \\
\hline 29 & 70 & 10.3 & 106.09 & 80 & 12.2 & 148.84 & 125.66 \\
\hline 30 & 70 & 10.3 & 106.09 & 80 & 12.2 & 148.84 & 125.66 \\
\hline
\end{tabular}

From the table above, that:

$\mathrm{N}=30$

$\sum X=1790$

$\sum Y=2033$

$\sum X^{2}=13296.7$

$\sum Y^{2}=9713.4$

$\sum X Y=10957.7$

a. Counting mean (average) and standard deviation (SD)

1. Mean and standard deviation (SD) of variable $\mathrm{X}$ (reading comprehension)

$$
\begin{aligned}
& (X)=\frac{\sum X}{N} \\
& =\frac{1790}{30} \\
& =59.7 \\
& S X^{2}=\frac{\sum X^{2}}{N-1} \\
& =\frac{13296.7}{30-1} \\
& =\frac{13296.7}{29} \\
& =58.5 \\
& S X=\sqrt{S X^{2}} \\
& =\sqrt{58.5069} \\
& =21.41
\end{aligned}
$$

2. Mean and standard deviation (SD) of Variable $Y$ (writing skill)

$$
\begin{aligned}
& Y=\frac{\sum Y}{N} \\
& =\frac{2033}{30} \\
& =68 \\
& S Y^{2}=\frac{\sum Y^{2}}{N-1} \\
& =\frac{9713.4}{30-1} \\
& =\frac{9713.4}{29} \\
& =335 \\
& S Y=\sqrt{S Y^{2}} \\
& =\sqrt{335} \\
& =18.3
\end{aligned}
$$


b. Counting the variable quality

1) Counting the quality of $X$ variable (Reading comprehension) with five scale

$\mathrm{M}+1.5(\mathrm{SD})=59.7+1.5(21.41)=59.7+32.115=91.815$

$\mathrm{M}+0.5(\mathrm{SD})=59.7+0.5(21.41)=59.7+10.705=70.405$

M- $0.5(\mathrm{SD})=59.7-0.5(21.41)=59.7-10.705=48.995$

M- $1.5(\mathrm{SD})=59.7-1.5(21.41)=59.7-32.115=27.585$

Table 6. Quality of Variable X (Reading Comprehension)

\begin{tabular}{llll}
\hline Average & \multicolumn{1}{c}{ Interval } & \multicolumn{1}{c}{ Qualities } & Criteria \\
\hline & $84-$ up & Very good & \\
\hline $79-83$ & Good & \\
\hline $73-78$ & Enough & \\
\hline 59.7 & $68-72$ & Low & \\
\hline
\end{tabular}

From the explanation above, that students' reading comprehension score is in lower score with interval value 67 -down with the average score 59.7 .

2) Counting the quality of $Y$ variable (writing skill) with five scale.

$\mathrm{M}+1.5(\mathrm{SD})=68+1.5(18.3)=68+27.45=95.45$

$\mathrm{M}+0.5(\mathrm{SD})=68+0.5(18.3)=68+9.15=77.15$

M- $0.5(\mathrm{SD})=68-0.5(18.3)=68-9.15=58.85$

M- $1.5($ SD $)=68-1.5(18.3)=68-27.25=40.75$

Table 7. Qualities of Variable Y (Writing Skill)

\begin{tabular}{clll}
\hline Average & Interval & Qualities & Criteria \\
\hline & $84-$ up & Very Good & \\
\hline & $79-83$ & Good & \\
\hline 68 & $73-78$ & Enough & \\
\hline $68-72$ & Low & Low \\
\hline & $67-$ down & Very Low & \\
\hline
\end{tabular}

From the explanation above, that students' writing skill score in lower score with interval value 6872 with the average score is 68 .

Note :

$$
\begin{aligned}
& R X Y=\frac{\sum X Y}{\sqrt{\left\{\left(\sum X^{2}\right)\left(\sum Y^{2}\right)\right\}}} \\
& =\frac{10953.72}{\sqrt{\{(13299.45)(9719709.1)\}}} \\
& =\frac{10953.72}{\sqrt{129125690}} \\
& =\frac{10953.72}{113363.34854}=0.963
\end{aligned}
$$

Rxy : Coefficient correlation

$\sum x y$ : the sum of variables $X Y$

Based on the calculation of coefficient correlation $\mathrm{X}$ toward $\mathrm{Y}$ is 0.963 and coefficient determination of both variable is 0.921 or $92.1 \%$.

To measure the significances correlation of $X$ variable toward $Y$ variable, the researcher used $t$ test, as follow:

$$
\begin{aligned}
& \text { test significances } \\
& t_{h}=\frac{\sqrt[r]{n-2}}{1-r^{2}} \\
& =\frac{0.96 \sqrt{30-2}}{\sqrt{1-0.963^{2}}}
\end{aligned}
$$




$$
\begin{aligned}
& =\frac{0.96 \sqrt{28}}{\sqrt{1-0,96^{2}}} \\
& =\frac{0.96 \times 5.29}{\sqrt{1-0,921}} \\
& =\frac{5,0784}{\sqrt{0,079}} \\
& =\frac{5,0784}{0,281} \\
& =18,07
\end{aligned}
$$

\begin{tabular}{|c|c|c|c|c|c|}
\hline \multirow{2}{*}{$\begin{array}{l}\text { Hypothesis } \\
\text { testing }\end{array}$} & \multirow{2}{*}{ Value } & \multicolumn{2}{|c|}{ Significance Level } & \multirow{2}{*}{ Information } & \multirow{2}{*}{ Hypothesis } \\
\hline & & $5 \%$ & $1 \%$ & & \\
\hline Rxy & 0,963 & 0,361 & 0,463 & Significance & Accepted \\
\hline
\end{tabular}

To know the counted analysis significant correlation, the researcher used test. It can be shown in table interpretation of $\mathrm{t}$ test below.

Table 8. Table of Correlation Product Moment Summaries

Based on the results of hypothesis testing using product moment correlation analysis with $t$ test obtained value rxy $=0.963$ then consulted on $r$ table both at the level of significance of $5 \%$ and $1 \%$ with the possibility:

a. If rxy is equal to or greater than $\mathrm{rt}$ (good for $1 \%$ or $5 \%$ level), then significant (hypothesis is accepted).

b. If rxy is equal to or less than $\mathrm{rt}$ (for either $1 \%$ or $5 \%$ level), then non significant (hypothesis is not accepted).

It is known that $\mathrm{r}$ table at the significance level of $5 \%=0.361$ and at the level of significance of $1 \%=$ 0.463 . Then the value of rxy of 0.963 is greater than the $r$ tabel either at $5 \%$ significance level or $1 \%$.

\section{CONCLUSION}

Based on the discussion, it can be drawn some conclusions as follows:

1) Level ability of reading comprehension in MTs Negeri 5 Pandeglang, Sukamanah Cikedal in 2017/2018 Academic Year is in very low category. This can be seen from the analysis that shows the mean value of 59.7 that is between the interval (67-down) and the value is very low category. This means that the level of reading comprehension of students is very low, in terms of reading and reading comprehension.

2) Writing skill level of MTs Negeri 5 Pandeglang. Sukamanah Cikedal in 2017/2018 Academic Year is in good category. This can be seen from the analysis that shows the mean value 68 , that is between the interval (68-72) and the value is very low category. This means the ability of students in writing is less.

3) Based on the quantitative analysis of the research results seen $r$ value of observation is 0.963 above product $\mathrm{r}$, with $\mathrm{rt}$ at significant level $5 \%=0,361$ and $\mathrm{rt} 1 \%=0.463$, in other words $\mathrm{r}$ observation equal to 0.963 bigger than $r$ table either at significance level $5 \%$ or $1 \%$. Thus "there is a significant positive relationship between reading comprehension and writing skills of MTs Negeri 5 Pandeglang.

\section{REFERENCES}

Arikunto, S. (2010). Prosedur Penelitian Suatu Pendekatan Praktik. Rineka Cipta: Jakarta.

Blachowicz, C, and Ogle, D. (2008). Reading Comprehension: Strategies for Independent Learners. New York: The Guilford Press.

Harmer, J. (2007). How to Teach English. London: Pearson Longman. 
Jacobs, H. L., Stehen, A. Z., Deanne, R., Wormuth, V., Faye, H., Jane, B., Hughey. (1981). Testing ESL Composition: A Practical Approach. Rowley: Newbury House Publisher, Inc.

Kendall, J. \& Khuon, O. (2006). Writing Sense: Integrated Reading and Writing Lessons for english Language Learners. Stenhouse Publisher.

Kwiantkowska-White, Bozena. (2012). Understanding Reading Comprehension Performance in High School Student. Ontario Kanada: Kingston University.

Nation, I. S. P. (2009). Teaching ESL/EFL Reading and Writing. Abingdon: Routledge.

Riduwan, (2011). Dasar-dasar Statistika. Bandung: Alfabeta.

Sugiyono, (2017). Metode Penelitian, Kualitatif, Kuantitatif dan RED, Alfabeta: Bandung. 